\title{
Improvement of Gypsum Soil Properties by using Novolac polymer
}

\author{
Dhay Waddy Mohammed ${ }^{\text {a }}$, Balqeea A. Ahmed ${ }^{\text {b }}$, Maysam Th. AL-Hadidic \\ ${ }^{a}$ M.Sc. Student,Department of Civil Engineering,University of Baghdad ,Baghdad, Iraq. E- mail address: dhaekh @ yahoo.com \\ ${ }^{\mathrm{b}}$ Assistant Proffessor, Department of Civil Engineering, University of Baghdad, Baghdad, Iraq. E-mail address:baahe7@yahoo.com \\ ${ }^{\mathrm{c}}$ Assistant Proffessor, Department of water resources Engineering, University of Baghdad, Baghdad, Iraq .E-mail address: maythamer@yahoo.com
}

\begin{abstract}
This paper is a tamped to improve the engineering properties of gypseous soil by adding novolac polymer. The soil samples brought from the west of Karbala city with $36 \%$ of gypsum content. The research was carried out by adding a different percentage of novolac polymer $(3 \%, 6 \%, 9 \% \mathrm{w} / \mathrm{W})$ respectively and comparing the results with other samples treated with cement in the same percentages. The targeted engineering properties are permeability, shear strength, and collapsibility. The results showed that $3 \% \mathrm{w} / \mathrm{W}$ of novolac gives the best improving in collapsibility which is improved to 57.8 while $6 \% \mathrm{w} / \mathrm{W}$ of novolac improved both the bearing capacity and the permeability which improved to ( 25.2 and $86.2 \%$ ) respectively.
\end{abstract}

Keywords: Gypseous Soil, Collapsibility, Permeability, Novolac Polymer,cement

\section{Introduction}

The gypseous soils are specifically considered as difficult unsaturated soil that hard to deal with during the construction of roads, strategic projects, and buildings which need in site improvement. The mechanical and physical properties of the gypseous soil affected by the amount of the gypseous in the soil and, the higher gypsum percent made this soils more sensitive to water [1]. Generally, Gypseous soils are widespread in different places of the world especially in dry and semi-dry areas where (Calcium Sulphate sources) when no enough amount of water for the washing process and it can be spread on the surface or in different depths of the soil [2], [3] .In natural condition, gypseous soil appears to be clearly strong, hard and capable to support a heavy load with small deformation but unfortunately, these mechanical properties affected when the water seeps to soil and start changing the arrangement of their molecules [4]. Moreover, the soil begins to deform and dissolution of the cementing gypsum occurs as the voids filled with water which finally increases incompressibility and reduces the bearing capacity. In the dry state, the strength in mechanical properties of the gypsum soils referred to first, the gypsum bond (cementation gypsum) between the particles second, the void filled with gypsum become stronger under the influence of compaction [5]. Some researchers set a lower rates limit to the percent of gypsum that effect on the engineering and mechanical properties of soil such as $(2 \%, 4 \%$, and 6\%) [6], [7]. However, to diminish the damage level caused by gypseous soils to the construction and building the soil improved. Commonly, there are two improving procedures: mechanical and chemical. In the past two decades, the properties of gypseous soils have been developed for the purpose of engineering construction. Many traditional materials used to improve the engineering properties of the gypseous soil such as cement, lime, fly ash. Even though these additive have good improvement results still consuming time and have to be in large quantities to achieve the improvement purpose [8] which made researches looking to use nontraditional materials such as Polymers that have good properties in terms of the tensile strength, pressure, and adhesion between the soil particles. Also, the polymers have good resistance to the effects of water and other chemicals. Some researchers studied the effect of polymer on a different type of soil like:

In 2010, Al-Neami [9] used (2, 4 and 6\%) clinker additive to treat gypsum soil from Al-Exandria, Babylon and found that the best clinker ratio was (4\%) which decreased the collapsibility of soil.

In 2010, AL-Numani [10] took a soil sample from Najaf that contains $35 \%$ of gypsum and treated it with different rates of cement content (4-8\%). The conducted laboratory tests indicated that increasing the cement content produced an increase in both the optimum water content and maximum dry density to (23.3 and $7.6 \%)$.

(A. Zandieh, 2010) [11] Used two types of polymer to improve sandy soil and his results showed an increase in compression strength by $(0.03-5.2) \mathrm{mPa}$.

In 2017, Ibrahim and Schanz [12] used mixture of 30\% of Silber sand and $70 \%$ of Pure Gypsum and treated it 
with different percentage of silicone oil to improve the engineering properties. The study results showed the silicone oil was able to improve the collapsibility and shear parameters of the gypseous soil.

Chao Xing1, 2018 [13] Who used polymer on the sand in a dry and wet condition and his results showed an increase in strength.

(Mohanned Waheed1, 2018) [14] Found that polymer is more suitable in coarse-grained soils, besides it is less effective in the soft soils.

In 2018, AL- Hadidi and AL-Maamori [15] used gypsum soil sample with $42.55 \%$ gypsum from Karbala city. Different water cement ratios (W/C) were used to decrease the collapsibility of earth canal and the results showed that $2 \%$ of $\mathrm{W} / \mathrm{C}$ led to decrease the collapsibility of soil.

In 2018, Vahid and Mohsen [16] took sand samples from Kerman city, Iran and mixed them with 2, 4, and 6\% of polymer with different period of treatment $(3,7$, and 28 days). They found that when the polymer content increased to $6 \%$, the unconfined compressive strength increased by ( $66.31 \%)$ in 28 days compared with 3 days.

In 2018, Al-Hadidi. and Ibrahim [17] used 6, 10, and $12 \%$ of polyurethane to reduce the soil erosion of irrigation canal which was made from gypsum soil in Karbala city with $41 \%$ gypsum. The researchers found the best percentage to use was $10 \%$ which reduced the erosion by $86.2 \%$.

The main goal of this study is to improve the properties of gypsum soil (collapsibility, permeability, bearing capacity, and compaction parameter) with small quantities and suitable prices by using new non-traditional materials novolac polymer

\section{The Material Used and Experimental Work A. Materials}

\subsection{Gypseous Soil}

To achieve the purpose of study, natural gypseous soil of $36 \%$ gypsum; is taken from one location about $100 \mathrm{~km}$ southwest of Baghdad (west of Karbala city on the edge of Anbar province). The samples were taken from depths $(0.5-1) \mathrm{m}$ below the natural ground surface. The unit weight of the soil in the location was $14.5 \mathrm{kN} / \mathrm{m}^{3}$ and the natural water content $5 \%$.The undisturbed soil samples were air dried, made homogenous, put in plastic bags and transported to soil mechanics laboratory at civil engineering department, college of engineering at AIQadisiyah University to evaluate the engineering properties of the soil. Figure (1) shows an image from Google earth for the location of soil sample.

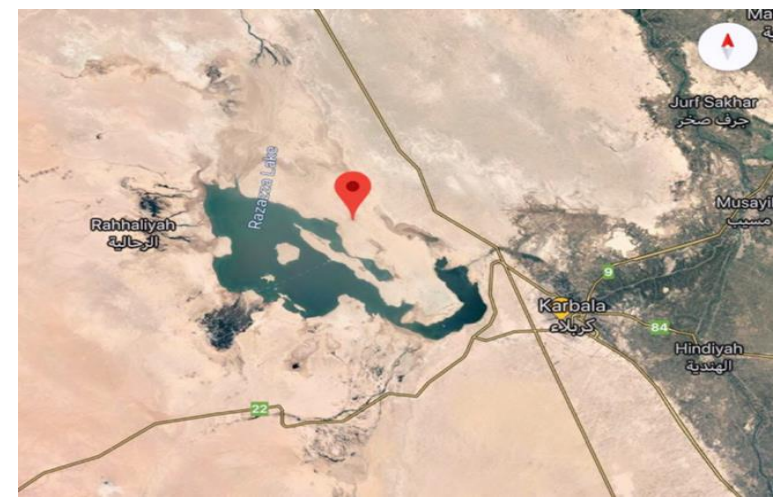

Figure (1): Site of soil sample

\subsection{The Cement}

For results comparing purposes, normal Portland cement has been used in this study to improved gypseous soil properties of. A Portland cement ratio of $(3,6,9) \%$ has been used during the tests. Table (1) showed the chemical composition of the used cement.

Table 1.The result of chemical test for cement

\begin{tabular}{|c|c|}
\hline Element & percentage \\
\hline $\mathrm{SiO}_{2}$ & 20.21 \\
\hline $\mathrm{Al}_{2} \mathrm{O}_{3}$ & 5.97 \\
\hline $\mathrm{C}_{3} \mathrm{~S}$ & 40 \\
\hline $\mathrm{C}_{2} \mathrm{~S}$ & 38 \\
\hline $\mathrm{C}_{3} \mathrm{~A}$ & 2.9 \\
\hline $\mathrm{C}_{4} \mathrm{AF}$ & 11.7 \\
\hline $\mathrm{MgO}$ & 4.3 \\
\hline $\mathrm{K}_{2} \mathrm{O}$ & 1.98 \\
\hline $\mathrm{Fe}_{2} \mathrm{O}_{3}$ & 4.1 \\
\hline
\end{tabular}

\subsection{Novolac Polymer}

Novolac polymer defined as the reaction between phenol-formaldehyde and phenol in acid catalyst media and consists of (5-6) \% of gasoline rings per molecule. The common properties of Novolac polymer are:

1. It has a small molecular weight and thermoplastic, which made it widely used in industry and binder for carbon bonding refractories because of his chemical resistance and electrical insulation [18].

2. Porous structure with less mechanical properties.

3 . The curing reaction for the novolacs polymer is carried out over $100^{\circ} \mathrm{C}$.

4. It has a density of (1-2) \% of the density of soil with color ranged from yellow to orange and $\mathrm{PH}$ number less than (7) [18]. 

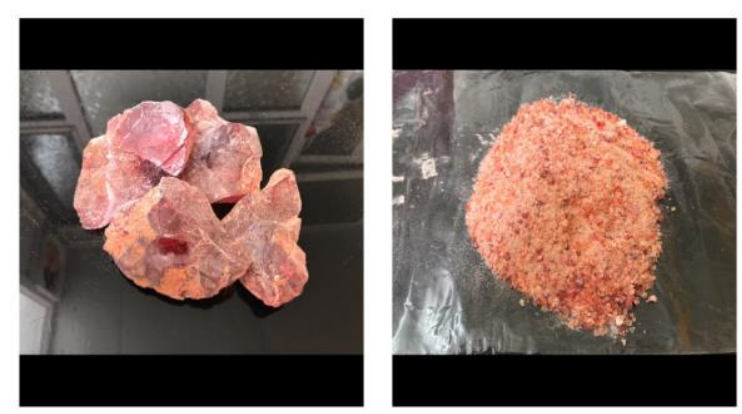

Figure.2 Novolac polymer

\section{B. Experimental Work}

\section{Compaction Test}

Standard Procter compaction test was carried out in accordance with (ASTM 698) method A [19]. A mold of $10 \mathrm{~cm}$ in diameter and $16.5 \mathrm{~cm}$ in height was used. The samples were compacted in three layers with 25 blows for each layer using a $2.5 \mathrm{~kg}$ hammer which is dropped from $30.5 \mathrm{~cm}$ height and this test was carried out for treated and untreated soils.

\section{Collapse Test}

Single collapse test was carried out according to the guide proposed by Jennings and Knights [20] and ASTM D5333 [21] on natural compacted and treated gypseous soil samples with various ratios of co-polymer, novolac polymer. The dry weight of specimens was obtained to determine the change in compressibility properties of gypseous soil by using specimens equipped with a ring which was $50 \mathrm{~mm}$ in diameter and $19 \mathrm{~mm}$ in height. The samples were left in the water for 24 hours with a pressure of $200 \mathrm{kPa}$ and then additional static load was applied until it reached $800 \mathrm{kPa}$ then samples were unloaded. The collapse index is obtained from the formula below by using (e-log p) graph under the effect of a certain stress level.

$$
C . P=\frac{\Delta e}{\left(1 \oplus e^{\circ}\right)}
$$

Where:

C.P = Collapse Potential.

$\Delta \mathrm{e}=$ void ratio before and after soaking.

$\mathrm{e}^{\mathrm{o}}=$ Initial voids ratio.

\section{Permeability Test}

Permeability test was performed for all samples (treated and untreated soil) according to ASTM D-2434 [22] .A mould with $10 \mathrm{~cm}$ in diameter and $13 \mathrm{~cm}$ in height was used. The mould was connected at the top inlet to a water source at a height of $180 \mathrm{~cm}$. The mould had a side outlet at the bottom for the water to flow out of the sample. The quantity of flow for a certain time period was collected and recorded. The permeability coefficient was calculated using the equation:

$$
K=\frac{Q}{(A \times I)}
$$

where:

$\mathrm{k}=$ coefficient of permeability.

$\mathrm{Q}=\mathrm{V} / \mathrm{T}$ quantity of water discharged.

$\mathrm{L}=$ the height of mold.

$\mathrm{A}=$ cross-sectional area of mold

$\mathrm{t}=$ total time of discharge.

$\mathrm{h}=$ the loss of water.

\section{Physical and Engineering properties of Gypseous Soil}

In order to determine the engineering properties of the soil has to be treated (gypseous soil), physical tests have been carried out in the lab and the results listed in Table (2). The specific gravity of the soil is determined according to BS 1377[23], but Kerosene was used instead of water due to the dissolution action of gypsum in water.

The soil was subjected to grain size distribution test according to ASTM D422 [24] to classify the soil. Figure (3) clearly shows that the soil can be classified as poor grade sand (SP) according to the Unified Soil Classification System (USCS).

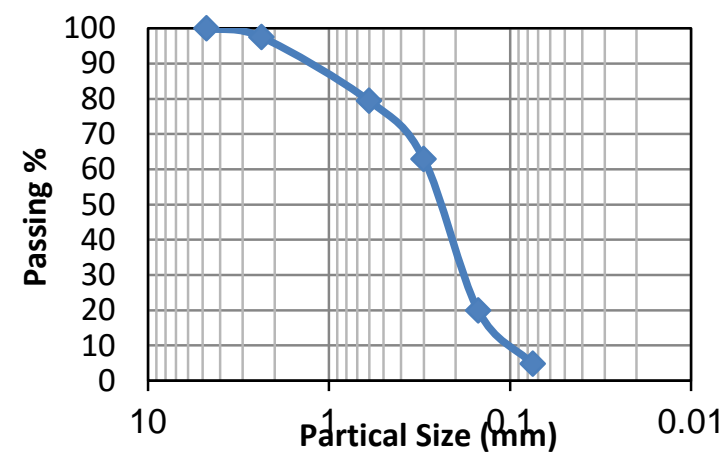

Figure .3 Grain size distributions of gypseous soil 
Table2: The results of physical properties tests of gypseous soil.

\begin{tabular}{|c|c|}
\hline Physical Property & Value \\
\hline Specific gravity, $\mathrm{G}_{\mathrm{S}}$ & 2.54 \\
\hline $\mathrm{D}_{10}$ & 0.1 \\
\hline $\mathrm{D}_{30}$ & 0.19 \\
\hline $\mathrm{D}_{60}$ & 0.3 \\
\hline Coefficient of curvature, $\mathrm{C}_{\mathrm{c}}$ & 1.203 \\
\hline Coefficient of uniformity, $\mathrm{C}_{\mathrm{u}}$ & 3 \\
\hline Unified Classification system & $\mathrm{SP}$ \\
\hline Maximum Dry Unit Weight & 16.28 \\
\hline$\gamma_{\mathrm{d}(\mathrm{max}}\left(\mathrm{kN} / \mathrm{m}^{3}\right)$ & 11 \\
\hline Optimum Water content $\omega_{\mathrm{opt}}(\%)$ & $1.7 \times 10^{-3}$ \\
\hline Permeability $(\mathrm{cm} / \mathrm{sec})$ & $\mathrm{C}=1.33$ \\
$\phi=30.2^{\circ}$ \\
\hline Direct Shear $\left(\mathrm{c}\left(\mathrm{kN} / \mathrm{m}^{2}\right)\right.$ and $\left.\phi^{\circ}\right)$ & 9.47 \\
\hline Single Collapse $(\%)$ & \\
\hline
\end{tabular}

\subsection{Chemical Tests}

The chemical and X-ray tests were carried out on gypseous soil used as shown in the results (see Table (3) and Table (4)). The chemical tests carried out at two different laboratories that specialize with this kind of tests the first one is located at the Karbala university of where the other one is the state company of Iraq Geological Surveying and Mining Baghdad lab.

Table3: The results of chemical properties tests of gypseous soil

\begin{tabular}{|c|c|}
\hline Chemical Property & Value \\
\hline Total (SO $\mathrm{SO}_{4}$ ) & 13.87 \\
\hline Total soluble salts (T.S.S \%) & 9.8 \\
\hline Gypsum content (\%) & 36 \\
\hline PH value & 8.21 \\
\hline CL (\%) & 0.00319 \\
\hline O.M (\%) & 0.86 \\
\hline
\end{tabular}

Table 4: The results of $X \_$ray test of gypseous soil

\begin{tabular}{|c|c|c|}
\hline Element & Wt. \% & Wt. \% sigma \\
\hline $\mathrm{O}$ & 53.46 & 0.3 \\
\hline $\mathrm{Na}$ & 0.56 & 0.07 \\
\hline $\mathrm{Mg}$ & 1.8 & 0.07 \\
\hline $\mathrm{Al}$ & 3.4 & 0.08 \\
\hline $\mathrm{Si}$ & 20.08 & 0.18 \\
\hline $\mathrm{S}$ & 5.06 & 0.1 \\
\hline $\mathrm{K}$ & 1.64 & 0.07 \\
\hline $\mathrm{Ca}$ & 11.65 & 0.14 \\
\hline $\mathrm{Ti}$ & 0.13 & 0.06 \\
\hline $\mathrm{Fe}$ & 2.23 & 0.12 \\
\hline
\end{tabular}

\subsection{Compaction test}

The results showed little change in maximum dry unit weight in improved soil where it increases with the increase of the cement content to $(5.22 \%)$ at $(9 \%)$ of cement. In another hand, the novolac polymer result showed that increasing the polymer content lead to a decrease in the maximum unit weight to $(1.72 \%)$ at $(9 \%)$ novolac polymer In case one, this increase can be attributed to the fact that the cement-filled the void between the soil particles. In case two, the decreasing the polymer results can be also returned to the reason that the polymer has a lightweight and this light density leading to replace some of the soil partial with novolac polymer creating a new soil structure with different volume .In another hand, the results showed a continuous increase in water content with both additive materials compares to natural soil this increasing due to increase in fine materials and water that required for the cement and novolac hydration.. Table (5) and figures (4 and 5) showed all the results of compaction tests for the soil in a natural state and after improving.

Table (5) : The result of compaction test of gypseous soil treated by cement and Novolac polymer

\begin{tabular}{|c|c|c|}
\hline Materials & $\begin{array}{c}\text { Maximum dry } \\
\text { unit } \\
\text { weight }\left(\mathbf{k N} / \mathbf{m}^{3}\right)\end{array}$ & $\begin{array}{l}\text { Optimum } \\
\text { moisture } \\
\text { content } \\
(\%)\end{array}$ \\
\hline Untreated soil & 16.28 & 11 \\
\hline Soil +3\% cement & 16.49 & 12.5 \\
\hline Soil +6\% cement & 17.13 & 13 \\
\hline Soil +9\% cement & 17.28 & 15 \\
\hline $\begin{array}{c}\text { Soil +3\% novolac } \\
\text { polymer }\end{array}$ & 17.18 & 13 \\
\hline $\begin{array}{c}\text { Soil +6\% novolac } \\
\text { polymer }\end{array}$ & 16.5 & 16 \\
\hline $\begin{array}{c}\text { Soil +9\% novolac } \\
\text { polymer }\end{array}$ & 16 & 17 \\
\hline
\end{tabular}

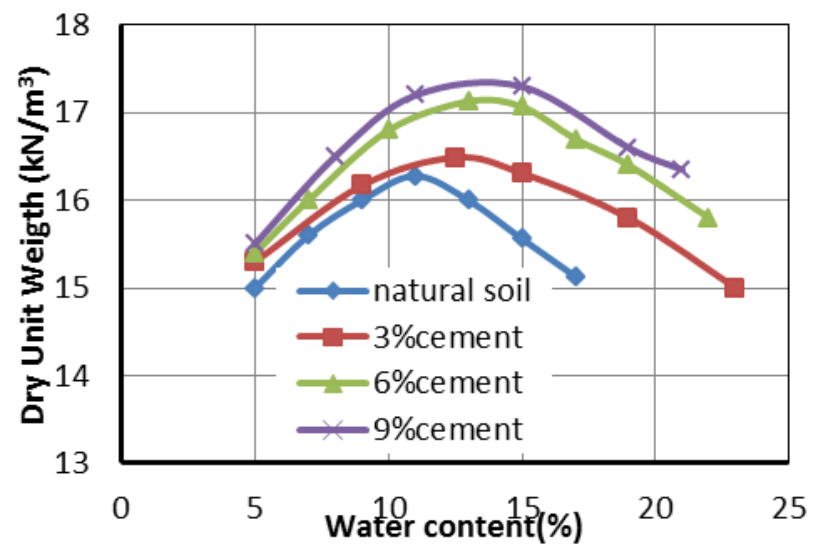

Figure 4: The Result of compaction test of gypseous soil treated by cement

\section{Results and Dissection}




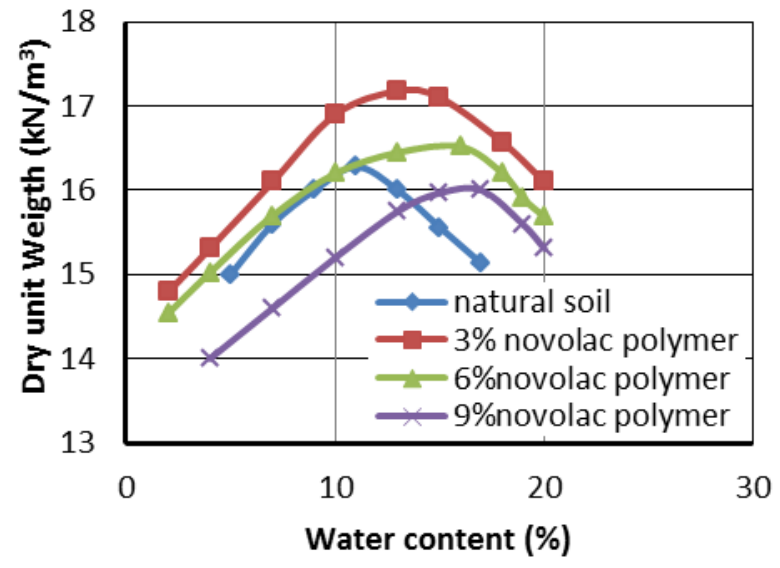

Figure 5: The result of compaction test of gypseous soil treated by Novolac polymer

\subsection{Collapse Test}

The collapse test was carried out for both natural and improving samples. All used samples were compacted to $(16.28 \mathrm{kN} / \mathrm{m} 3)$ maximum unit weight and $(11 \%)$ optimum water content. It has been noticed that the collapse potential decreased to $(64.4 \%)$ at $(6 \%)$ of cement. Also, the results showed that additive cement starts to work inversely on collapse after that. However, compared to cement the novolac polymer results showed opposite behaviour where the collapse potential increased by increasing the polymer content. The results showed that adding (3\%) of novolac polymer decreased the collapse by $(57.8 \%)$. The reduction in collapse potential with additive cement can be assigned to the fact that the cement work on increasing the connection between soil particles creating a stronger structure. In novolac polymer the reduction can be assigned to the fact that the polymer flocculates the soil particles by spreading and sliding them resulting in fewer connections between them which is finally lead to an increase in the volume of samples and reduction in dry unit weight. Tables (6), (7) and Figure (6) below shows the collapse test results to all tested samples.

Table (6): The result of collapse potential (\%)

\begin{tabular}{|c|c|}
\hline Case & $\begin{array}{c}\text { Collapse } \\
\text { potential (\%) }\end{array}$ \\
\hline Untreated soil & 9.47 \\
\hline Soil+3\%cement & 4.26 \\
\hline Soil+6\%cement & 3.37 \\
\hline Soil+9\%cement & 3.53 \\
\hline $\begin{array}{c}\text { Soil +3\% novolac } \\
\text { polymer }\end{array}$ & 4 \\
\hline $\begin{array}{c}\text { Soil +6\% novolac } \\
\text { polymer }\end{array}$ & 4.58 \\
\hline $\begin{array}{c}\text { Soil +9\% novolac } \\
\text { polymer }\end{array}$ & 6.8 \\
\hline
\end{tabular}

Table (7): Summary of the percentage of improving in the collapse potential $(\%)$

\begin{tabular}{|c|c|c|c|}
\hline $\begin{array}{c}\text { Percentage } \\
\text { added }\end{array}$ & $3 \%$ & $6 \%$ & $9 \%$ \\
\hline Material & & 64.4 & 62.72 \\
\hline Cement & 55 & 51.85 & 28.19 \\
\hline $\begin{array}{c}\text { Novolac } \\
\text { polymer }\end{array}$ & 57.8 & 6 \\
\hline
\end{tabular}

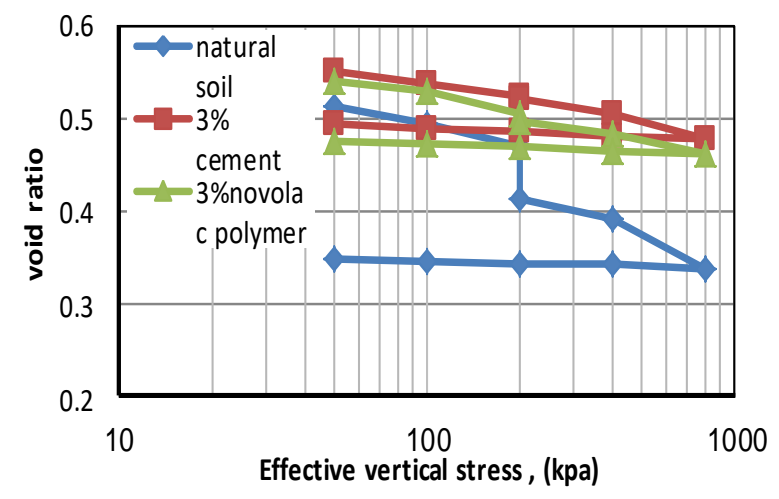

(a)

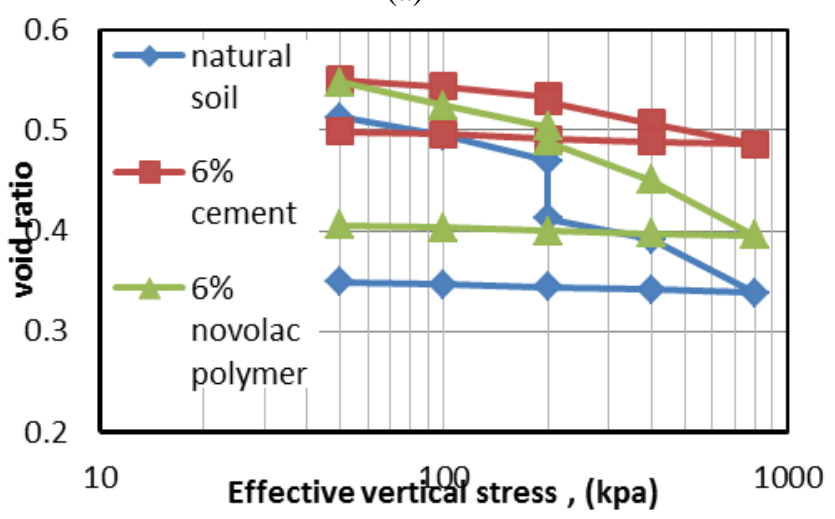

(b)

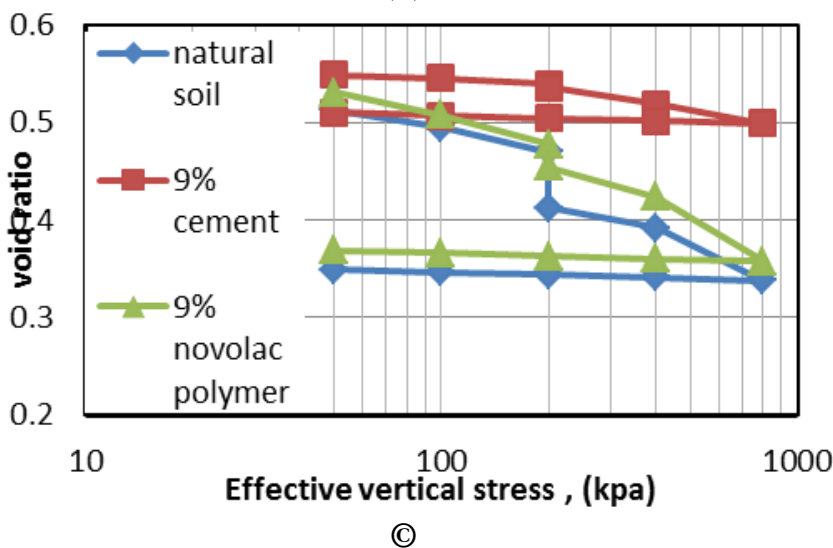

Figure 6(a,b,c): Single collapse test of gypsous soil treated by cement and novolac polymer

\subsection{Permeability test}

All the permeability tests result details are shown below in the Table ( 8 and 9 ). The test has been contacted 
to natural and treated soil that compacted to the maximum dry unit weight. It has been noticed that the permeability coefficient decreased as the additive cement content increased. The results showed that $(9 \%)$ of additive cement able to decrease the permeability coefficient by $(88.65 \%)$.In another hand, $(6 \%)$ of novolac polymer help to minimize the permeability coefficient by $(86.2 \%)$ as the best improvement value compares to others. Both materials work as waterproofing by covering the gypsum particles and filled the voids among them resulting in a reduction in the dissolution of gypsum in water and reduction in the destruction of soil mass structure.

Table (8) : The result of permeability test of gypseous soil treated by cement and novolac polymer compare to natural soil

\begin{tabular}{|c|l|l|l|}
\hline Material & $3 \%$ & $6 \%$ & $9 \%$ \\
\hline cement & $3.5 \times 10^{-4}$ & $3 \times 10^{-4}$ & $1.93 \times 10^{-4}$ \\
\hline $\begin{array}{c}\text { Novolac } \\
\text { polymer }\end{array}$ & $5.31 \times 10^{-4}$ & $2.35 \times 10^{-4}$ & $3.69 \times 10^{-4}$ \\
\hline $\begin{array}{c}\text { Natural soil } \\
\text { under } \\
\text { compaction }\end{array}$ & $1.7 \times 10^{-3}$ & \\
\hline
\end{tabular}

Table (9): The summery of improving in permeability factor compare to natural soil

\begin{tabular}{|l|l|l|l|}
\hline Material & $3 \%$ & $6 \%$ & $9 \%$ \\
\hline Cement & 79.4 & 82.35 & 88.65 \\
\hline $\begin{array}{c}\text { Novolac } \\
\text { polymer }\end{array}$ & 68.8 & 86.2 & 78.3 \\
\hline
\end{tabular}

\subsection{Direct shear test}

The bearing capacity has been studied for both natural compacted and improved soils using Terzaghi equations and the shear strength parameters which are calculated in the laboratory by running the direct shear tests [25]. It' has been noticed that increasing both cement and novolac polymers contents to $(6 \%)$ able to improve the bearing capacity of soil by ( 104 and $25.2 \%$ ) respectively. any farther increments result in a decrease in the bearing capacity of the tested samples. This improvement in results can be assigned to the fact that these materials work on increasing the bonding and cementation between the soil particles resulting in a high value of cohesion parameter.(see Table (10 )and (11)).

Table (10) : The result of bearing capacity of gypseous soil treated by cement and novolac polymer

\begin{tabular}{|l|l|l|l|}
\hline Material & $3 \%$ & $6 \%$ & $9 \%$ \\
\hline Cement & 403.76 & 644.63 & 536.45 \\
\hline $\begin{array}{l}\text { Novolac } \\
\text { polymer }\end{array}$ & 310.57 & 395.46 & 279.1 \\
\hline Natural soil & 315.95 & \multicolumn{2}{|l|}{} \\
\hline
\end{tabular}

under

compaction

Table (11) : The summery of result of changing the bearing capacity compare to natural soil under compaction

\begin{tabular}{|l|l|l|l|}
\hline Material & $3 \%$ & $6 \%$ & $9 \%$ \\
\hline Cement & 27.8 & 104 & 69.8 \\
\hline $\begin{array}{c}\text { Novolac } \\
\text { polymer }\end{array}$ & -1.7 & 25.2 & 11.66 \\
\hline
\end{tabular}

\section{Conclusion}

1. The change in maximum dry unit weight was no clear enough (increase/decrease) where the results showed that the maximum dry unit weight increased by increasing the cement content while it behaved reversely with novolac polymer (decreased by increasing the additive amount).

2. The additive materials contribute to redact the collapse potential where the results showed that (6\%) of cement content able to minimize the collapse by $(64.4 \%)$ while only $(3 \%)$ of novolac polymer helps to decrease it by $(57.8 \%)$.

3. The permeability coefficient decreased with increasing the amount of both additive materials especially at $(9 \%)$ of cement and $(6 \%)$ of the novolac polymer.

4. The bearing capacity has been increased with both additives (cement and novolac polymers) where the results showed that only $(6 \%)$ of each cement or novolac able to improve the bearing capacity by $(104 \%$ and $25.5 \%)$ respectively.

5. In terms of cost, novolac material is expensive. The basic structure of this material is oil derivatives and the high price of it is due to the technology used in the manufacturing and importing as mentioned before. However, if there is a production factory inside the country that provides such kind of additives, the cost might be lower or even close to the cement price.

\section{References}

[1] Al-Kaabi, F. S. (2007)"Distribution of the Gypsiferous Soil in Iraq" „State Company of Geological Survey and Mining, Iraq Report,.3044,.

[2] FATTAH, Mohammed Y.; AL-ANI, Mohammad M.; AL-LAMY, Mahmoud T. A. (2013)" Treatment of collapse of gypseous soils by grouting. Proceedings of the Institution of Civil Engineers-Ground Improvement166.1: p.p 32-43. 
[3] Al-Emami, O.H., (2007) "Collapsibility of gypseous soil under fluc-tuation of ground water table", M.Sc. Thesis, Building and Construction Department, University of Technology, Iraq.

[4] Al-Badran, Y. M. (2001)"Collapse Behavior of AlTharthar Gypseous Soil" M.Sc. Thesis, Civil Engineering Department, University of Baghdad, Iraq.

[5] Nashat, I.(1990) "Engineering Characteristic of some Gypseous Soils in Iraq", PhD Thesis, Civil Engineering Department, University of Baghdad ,Iraq.

[6] Saaed, S.A. and Khorshid, N.N. (1989)"Some basic characteristics of the Gypsiferous soils of Al-Dour" Proceeding of the 5th Scientific Conference, Building Research, ,4, Part 2.76-88, Baghdad. (In Arabic).

[7] Al-Barzanji, A. I.(2003) "Traditional and Lime Stabilized Stone Columns in Gypseous Soil", M.Sc. Thesis, University of Technology ,Baghdad, Iraq.

[8] Woods , (1960) " High way engineering Handbook " chapter 21 , McGraw Hill Book Company ,New York, 1960.

[9] Al-Neami,M.A.M, ,(2010) "Improvement Of Gypseous Soil By Clinker Additive"Eng.\&Tech.Journal , Vol 28, No. 19.

[10] AL-Numani, Huda NT. (2010)"Improvement of the mechanical properties of gypseous soil by additives". AlQadisiyah Journal for Engineering Sciences, Vol. 3.3 p.p 383-392.

[11] Zandieh, Ali Reza; Yasrobi, S. Shahaboddin. Retracted article,(2010)" Study of factorsaffecting the compressive strength of sandy soil stabilized with polymer". Geotechnical and Geological Engineering, Vol. 28.2: p.p 139-145.

[12] Ibrahim, A.N. and Schanz,T (2017)" Gypseous soil improvement by silicone oil". Al-Nahrain Journal for Engineering Sciences, 20(1), pp.49-58.17.

[13] Chao Xing1, Xueyan Liu2, and Kumar Anupam (2018) "Response of Sandy Soil Stabilized by Polymer Additives""

[14] Mohanned Waheed1, (2018)" Improvement of engineeringsoil properties using non-traditional additives"... Journal Article published 2018 in MATEC Web of Conferences volume 162 on page 01027.

[15] AL- Al-Hadidi, M.T. and AL-Maamori, Z.H.(2018)." Improvement of Earth Canals Constructed on a Gypseous Soil By Cement". Association of Arab Universities Journal of Engineering Sciences, vol. 25(5), pp.171-189.
[16] Toufigh, Vahid; Rahmannejad, Mohsen. (2018)"Influence of Curing Time and Water Content on Unconfined Compressive Strength of Sand Stabilized Using Epoxy Resin". International Journal of Engineering, vol. 31.8: p.p 1187-1195.

[17] Al-Hadidi M. Th. and Ibrahim A. G.,(2018) " Improvement of Gypsum Soil by Using Polyurethane to Reduce Erosion and Solubility of Irrigation Canals" International Journal of Engineering \& Technology (pp. 372-376.

[18] Gardziella et al.(2000)"Guidelines for Future Developments in Phenolic Resins and Related Technologies" Book Chapter published 2000 in Phenolic Resins, p.p24 to 82 .

[19] ASTM (D698), "Standard Test Methods for Laboratory Compaction Characteristics of Soil Using Standard Effort $(600 \mathrm{KNm} / \mathrm{m} 3) "$, Reprinted from the Annual Book of ASTM Standards .Copyright ASTM, 2012,Vol.4, No.8.

[20] Jennings, J. and Knight, K.(1957) "A guide to construction on or with materials exhibiting additional settlement due to collapse of grain structure", in 'Proceeding of 6th Regional Conference for Africa on soil mechanics and Foundation Engineering .

[21]ASTM D5333,(2003) "Standard Test Method for Measurement of Collapse Potential of Soils", Annual Book of ASTM Standards, Vol.04.08, Philadelphia, PA, ASTM, USA. Copyright, ASTM International, 100 Barr Harbor Drive, PO Box C700, West Conshohocken, United States.P19428-2959.

[22]American Society of Testing and Materials (ASTM),(2006)"Standard Test Method for permeability of Granular Soils (constant Head) ASTM D2434-68 ,West Conshohocken, Pennsylvania, USA .

[23] BS 1377 - 2 (British Standard Institution),(1990) "Method of test for soils for civil engineering purposes". British Standard Institution, London, UK.

[24] American Society for Testing and Materials (ASTM), (2002)"Standard test method for particle size analysis of soils ", ASTM D422 International, West Conshohocken, Pennsylva-nia, USA.

[25] Terzaghi K,(1943) "Theoretical Soil Mechanics." Wiley, New York. 